\title{
AFGHAN STUDENTS' SATISFACTION FROM ONLINE LEARNING DURING COVID-19 AT KANDAHAR UNIVERSITY, KANDAHAR, AFGHANISTAN
}

\author{
Abdul Nafi Himat \\ General Teaching Manager of Agriculture Faculty, \\ Mirwais Khan Nika Zabul Institute of Higher Education \\ Zabul, Afghanistan \\ E-mail: abdulnafi.himat2017@gmail.com \\ Mohammad Hanif Takal \\ Nominated Teaching Assistant \\ Mathematics Department, Education Faculty \\ Mirwais Khan Nika Zabul Institute of Higher Education \\ Zabul, Afghanistan \\ E-mail: mohammadhaniftakal@gmail.com \\ Mohammad Farooq Hakimi \\ Senior Teaching Assistant \\ Head of Mathematics Department \\ Education Faculty, Kandahar University \\ Kandahar, Afghanistan \\ E-mail: Farooq123hakimi@gmail.com
}

\begin{abstract}
This purpose of this study was to examine the satisfaction of Afghan students from online learning during COVID-19 at Kandahar University, Kandahar, Afghanistan. This research used a quantitative approach, and the learners were from several departments of Education Faculty as well as they were selected through random sample. Similarly, the questionnaire was the main instrument of this study. As well as, three hundred and forty students took participation. After collecting the data, it was analyzed by implementing IBM 24 version of (SPSS). Moreover, the findings of this research indicated that majority students were not satisfied from distance education because learners could not learn from online education compare to traditional classroom setting, learners did not have access to internet-based learning through computer or smartphone, students did not prefer web-based learning, and learners did not seek the same descriptions of lessons on online learning process compare to traditional method of classroom. Also, online learning did not able students to learn independently. However, they were somehow satisfied from the role of teachers who played their role as a facilitator during e-learning process.
\end{abstract}

Keywords: ICTs, Technology, Online Learning, Students' Satisfaction.

JEL Classification Codes: A19, B10, B25, C10, C53 


\section{INTRODUCTION}

Information and Communication Technologies (ICTs) has created new opportunities for education (Askar \& Halici, 2004). Thus, learning can occur anywhere and anytime, even there is a geographical separation between learners and lecturer. In distance education, (ICTs) can make a bridge among students and teachers as well as through (ICTs) they can easily interact with each other (Moore \& Kearsley, 1996). Similarly, (ICTs) are digital tools or sources which control, spread, and create information as well they include both traditional such as radio, television, and fax as well as new devices or new technologies are internet, teleconferencing, interactive CDs, DVDs, email, the World Wide Web, virtual realities, hypertext, hardware, and software (Apena, 2012; Olusola \& Alaba, 2011; Wang \& Woo, 2007). These all tools control and process information and also facilitate communication (Apena, 2012; Koustourakis, Panagiotakopoulos $\&$ Vergidis, 2008). Also, the development of technology makes distance education all possible and encourages more people to become engaged in learning, specifically adults hence, e-learning has received much attention of the educational contexts (Askar et al., 2004; Allen, Elaine \& Seaman, 2015). Moreover, technology has clearly made the life of humans easier as well as it enhances the process of learning and teaching (Ala-Mutka, Punie \& Redecker, 2008).

In the same way, e-learning is a system of learning based on technology which use electronic technologies in order to access educational curriculum or materials outside the traditional classrooms or educational campus (Jama, Mapesela \& Beylefeld, 2008). Likewise, online education is a method of instruction which allow learners and teachers to interact with each other through using internet as a method of communication (Al-Asfour, 2012). Distance education provides an independent student-centered and lecturer facilitated engagement that facilitate interaction with teachers and students which may not always be possible within the traditional classroom settings (Michailidou \& Economides, 2003). Besides, e-learning refers to a course, program or degree that is completed through online as well as it is the practice of electronic education systems such as computer, internet and multimedia disks (Salamat, Ahmad, Bakht \& Saifi, 2018; Wantling, Weight, Gallaher, Fleur, Wang \& Confer, 2000). Additionally, internet-based learning refers to a situation where the interaction between learners and teacher is performed through online system (Ajadi, Salawu \& Adeoye, 2008). In computer-assisted learning, students are far away from the campus, and they are educated through a mixture of media (Mahmood, Mahmood \& Malik, 2012). According to Franklin \& Nahari (2018) e-learning is also known as online learning, internet learning, computer-assisted instruction, web-based learning, distributed learning, distance education, computerized electronic learning, or internetbased learning.

The use of web-based learning is not a new phenomenon in some parts of all over the world. As well as, the use of online learning attracted the attention of all educational contexts, particularly when the government of all countries closed schools and universities due to COVID19. Therefore, it diverts the attention of all educational contexts, especially of those contexts that did not have distributed learning programs. In Afghanistan, when all educational campuses closed, schools and universities tried to perform the process of teaching through internet-based learning because they did not have other ways. Therefore, in Afghanistan the Ministry of Higher Education (MoHE) tried to provide the process of teaching by lecturers to students through webbased learning process. After, the (MoHE) get benefited from the Higher Education Learning Management System (HELMS) in order to provide teaching materials to students. Furthermore, the problem of this study was that most of the learners claimed during COVID-19 that they do not have zeal with distance learning, and even many students do not want to participate on the 
process of online learning as well many students claimed that they do not have access to internet even laptops and smartphones in order to access online learning. Similarly, a study carried out at Kabul Polytechnic University, Afghanistan by Sokout \& Usagawa (2018) the researchers stated that Afghanistan is still having troubles with reliability of internet connection, electricity, ICTs centers and quality of service. In addition, the researchers further stated on their study that having proper infrastructure is one of the major necessities for the implementation of e-learning programs in Afghanistan. Furthermore, there are limited studies conducted regarding e-learning; specifically, regarding students' satisfaction from online learning at Kandahar University, Kandahar, Afghanistan. Consequently, this study tries to fill the gap through conducting this research. Lastly, this study would help not only with (HELMS) of Afghanistan as well as with Kandahar University in order to bring modification in this part.

\section{Objective of the Research}

- To investigate the satisfaction of students from online learning during COVID-19 at Kandahar University, Kandahar, Afghanistan.

\section{LITERATURE REVIEW}

Kuo, Walker, Belland \& Schroder (2013) investigated the satisfaction of students from online education programs at College of Education, Western University. The findings showed that learner-instructor interaction, learner-content interaction, and internet self-efficacy were good predictors of students' satisfaction while interactions between learners and self-regulated learning did not contribute to student satisfaction. The study further stated that learner-content interaction is the largest unique variance of student satisfaction. Likewise, as e-learning has taken the place of traditional or face-to-face educational environments (Mahmood et al., 2012). Therefore, according to studies carried out by Lao \& Gonzales (2005); Northrup (2009); Swan, Shea, Fredericksen, Pickett, Pelz \& Maher (2000) that the following parts are important for the satisfaction of students from online teaching, interaction among students, quality and timely interaction between learner and lecturer, consistent course design across courses, technical support availability, and flexibility of online courses compared to face-to-face. Likewise, factors that affect students' satisfaction include interaction with teachers, active discussion between students and clarity of program design (Swan, 2001). Also, support of stuff and high quality instructional services also result in higher students' satisfaction with the educational environment (Yukselturk \& Yildirim, 2008). Moreover, Harsasi, \& Sutawijaya (2018) conducted a study at Terbuka University, Indonesia. The researchers wanted to investigate the factors that effect on learners' satisfaction from internet-based learning. The findings of this study asserted that the structure of course, flexibility of online tutorials and technology quality were the factors which had impacts on learners' satisfaction.

A study conducted by Zaheer, Babar, Gondal \& Qadri (2015) in Pakistan to measure the satisfaction of students from e-learning. The findings showed that majority students are highly satisfied from distance learning provided by the University. Similarly, Simpson (2012) examined students' perceptions of quality and satisfaction in regionally accredited online courses on ten different institutions. The findings revealed that students are highly satisfied because the students reported that they were comfortable when they received their lesson through online mode. Moreover, a research conducted at Anatolian University on nine hundred and seventeen undergraduate learners in Turkey by Sahin (2007) the researcher analyzed the characteristics of online learning environment as well the relationship among satisfaction of students from distance education and learning environments. The findings indicated that students had a higher level of 
satisfaction from distance learning. The study further stated that personal relevance, instructor support, active learning and authentic learning were the factors which significantly and positively increased students' satisfaction. The findings reveled more that personal relevance was the strongest predictor of students' satisfaction. In addition, students who linked their course content with their personal experiences were satisfied from online learning. The findings of this study added more that computer-assisted learning is student-centered method because lecturer support such as, timely assist, useful feedback, and easy communication were the key factor for students' satisfaction on distance education.

Likewise, a comparative study conducted in Pakistan to compare the level of students' satisfaction at Allama Iqbal Open University's (AIOU) distance learning and International Islamic University's traditional classroom programs of educational psychology course taught by the same instructor. The findings asserted that internet-based learning and traditional classroom students experienced a high level of satisfaction. Moreover, it was determined that there was very slightly difference in the levels of students' satisfaction on the distance learning and traditional classroom students (Mahmood, et al., 2012). Similarly, a study carried out at (AIOU), Islamabad, Pakistan which investigated the relationship between students' satisfaction on distance learning. The results of this study indicated that majority of the students had high level of satisfaction regarding students-instructor interaction, instructor performance and course evaluation (Ali, Ramay \& Shahzad, 2011).

In addition, Arif, Ameen \& Rafiq (2017) investigated students' satisfaction from the use of web-based services at (AIOU), Pakistan. The study used pilot tested questionnaire-based survey to collect data from 388 students, and they were from eleven different academic departments of the Faculty of Social Science and Humanities. The findings of this study discovered that majority of the students $(82 \%)$ were satisfied from the use of web-based services at (AIOU). The study further showed that t-test analysis showed that no difference was found in the opinion of male and female respondents in terms of their satisfaction with the use of web services. Moreover, ANOVA results indicated that there was no significant difference illustrated in satisfaction with the use of the web services among the respondents enrolled in different disciplines of the faculty. Additionally, a study carried out by Al-Asfour (2012) at a private University and determined students' satisfaction of statistics online courses. The results of this research asserted that majority students were satisfied from online learning. Similarly, a qualitative study conducted in order to determine the satisfaction levels of undergraduate students at a private University in courses delivered through distance education. The findings displayed that students have satisfaction from distance education courses (Caliskan, Suzek \& Ozcan, 2017). Likewise, a study carried out on students from a modular course of the School of Humanities, Hellenic Open University, Greece. The researchers investigated distance learning factors in a blended distance education environment, namely the student-tutor interaction, the performance of the teacher and the course evaluation by the students. Majority students were satisfied from their studies. Moreover, learners were satisfied from the instructor's performance and communication and interaction with their lecturer (Anagnostopoulou, Mavroidis, Giossos \& Koutsouba, 2015).

Likewise, a study conducted on online distance universities of Japan to investigate the undergraduate students' ideas and learning preferences in regard to five aspects of distance learning such as, student-teacher interaction, learner content interaction, student-student interaction, learner-interface interaction and learner interaction. The results declared that students were generally satisfied from their learning. The study further showed that learning satisfaction 
was higher for those students who had persevere with online learning challenges, students who found it easy to use computers were more satisfied than those who did not (Bray, Aoki \& Dlugosh, 2008). In addition, Kutluk \& Gulmez (2012) carried out a study to find out distance education learners' satisfaction level and efficiency in education quality at Accounting Distance Education Program in two universities of Turkey. The findings asserted that students were satisfied. Likewise, Nadia \& Iqbal (2011) conducted a research to measure the satisfaction level of students towards e-learning in higher Education, Pakistan. The findings revealed that students were satisfied from e-learning programs. Also, Agbanu, Sonyo, Region \& Ahiase (2018) conducted a research at University of Education, Winneba in the Volta Region campuses, Ghana. As well as, the researchers wanted to identify factors that influence students' satisfaction on distance education programs. The results showed that administrative support services that focus on students, course evaluation by students, the instructor's performance, and the student instructor interactions influence students' satisfaction.

Moreover, Roach \& Lemasters (2006) carried out a research in the United States to find the satisfaction of learners from online learning. The findings indicated that students on the online program were satisfied from the courses. In addition, Irungu (2016) investigated the factors that influence on learners' satisfaction from online learning. The results asserted that large extent of students were satisfied from online learning which offered through the School of Continuing and Distance Studies at University of Nairobi, Kenya. As well, majority respondents showed their satisfaction by stating that they would still enroll through distance education. Similarly, the study indicated more that students' preferred distance learning as opposed to regular classroom-based learning. Likewise, many learners disclosed that their expectations were met through the program and participants stated that they would encourage friends and relatives to enroll distance learning. The study further disclosed that personal characteristics, learning content and leaner support services were the factors which influenced students' satisfaction. Furthermore, researcher investigated online tutoring system in Computer Science Multimedia at University College Shahputra. The findings showed that online tutoring system is interesting, and pleasant to be used. The students agreed that online learning gave them flexibility on their learning compared to traditional learning. The study indicated more that students were satisfied from the content, structure, and had a motivation on using online tutoring system (Arif, \& Khalifa, 2012). Whereas, Sunkara \& Kurra (2017) conducted a research in India to analyze the tendencies of learners about the use of online learning systems in teaching and learning process. The findings of the study disclosed that students were not fully satisfied from distance learning whereas $77.49 \%$ of them were comfortable with using internet and web-based services for learning while $51.93 \%$ always able to use technology and internet for learning process.

\section{Research Design}

\section{RESEARCH METHODOLOGY}

This study tried to identify the satisfaction of learners from e-Learning during COVID-19 at Kandahar University. A quantitative approach was employed for this study.

\section{Population and Sampling}

The population of this study was 340 students and they were selected through a random sample from Mathematics, Chemistry, Biology, Physics, English, Pashto, Dari, Physical Education and Computer Learning Departments of Education Faculty, Kandahar University, Kandahar, Afghanistan. Additionally, the learners were from all four levels freshmen, sophomore, junior 
and senior as well as out of three hundred and forty (340), two hundred and ninety-one (291) were males and forty-nine (49) were females.

\section{Instrument and Data Collection Procedure}

The instrument of this research was questionnaire and it had two parts. The first part was the demographic data of the participants, and the second part was related to students' satisfaction from online learning. The questionnaire had sixteen items, and they were asked from the participants through using the Likert scale beginning from "strongly disagree to strongly agree". Similarly, the questionnaire was translated into native language (Pashto) of the respondents, and then the data was collected from the respondents.

\section{Validity and Reliability of the Questionnaire}

The questionnaire was checked for several times before collecting the data from the participants of the study. Moreover, somehow changes brought in the items, especially in the order of the statements. Furthermore, the reliability the questionnaire was excellent (0.9).

\section{Data Analysis Procedure}

The data was analyzed through the use of 24 versions of SPSS. The frequency and percentage of the participants' responses are reported with items in a table.

\section{FINDINGS}

Table 1. Shows the satisfaction of students from online leaning at Kandahar University

\begin{tabular}{|c|c|c|c|c|c|c|}
\hline No & Item & $\begin{array}{l}\text { Strongly } \\
\text { Disagree }\end{array}$ & Disagree & $\begin{array}{l}\text { Somehow } \\
\text { Agree }\end{array}$ & Agree & $\begin{array}{l}\text { Strongly } \\
\text { Agree }\end{array}$ \\
\hline 1 & $\begin{array}{l}\text { I could learn more in a distance } \\
\text { education environment than in a } \\
\text { traditional classroom. }\end{array}$ & $\begin{array}{c}182 \\
(53.5 \%)\end{array}$ & $\begin{array}{c}103 \\
(30.3 \%)\end{array}$ & $\begin{array}{c}31 \\
(9.1 \%)\end{array}$ & $\begin{array}{c}16 \\
(4.7 \%)\end{array}$ & $\begin{array}{c}8 \\
(2.4)\end{array}$ \\
\hline 2 & $\begin{array}{l}\text { I had access online learning } \\
\text { through computer. }\end{array}$ & $\begin{array}{c}173 \\
(50.9 \%) \\
\end{array}$ & $\begin{array}{c}94 \\
(27.6 \%) \\
\end{array}$ & $\begin{array}{c}34 \\
(10.0 \%) \\
\end{array}$ & $\begin{array}{c}29 \\
(8.5 \%) \\
\end{array}$ & $\begin{array}{c}10 \\
(2.9 \%) \\
\end{array}$ \\
\hline 3 & $\begin{array}{l}\text { I preferred distance learning } \\
\text { than face-to-face (traditional } \\
\text { method). }\end{array}$ & $\begin{array}{c}169 \\
(49.7 \%)\end{array}$ & $\begin{array}{c}92 \\
(27.1 \%)\end{array}$ & $\begin{array}{c}41 \\
(12.1 \%)\end{array}$ & $\begin{array}{c}32 \\
(9.4 \%)\end{array}$ & $\begin{array}{c}6 \\
(1.8 \%)\end{array}$ \\
\hline 4 & $\begin{array}{l}\text { I got the same explanations on } \\
\text { online learning as I received in } \\
\text { the traditional method. }\end{array}$ & $\begin{array}{c}151 \\
(44.4 \%)\end{array}$ & $\begin{array}{c}98 \\
(28.8 \%)\end{array}$ & $\begin{array}{c}56 \\
(16.5 \%)\end{array}$ & $\begin{array}{c}27 \\
(7.9 \%)\end{array}$ & $\begin{array}{c}8 \\
(2.4 \%)\end{array}$ \\
\hline 5 & $\begin{array}{l}\text { I was satisfied from online } \\
\text { learning. }\end{array}$ & $\begin{array}{c}149 \\
(43.8 \%)\end{array}$ & $\begin{array}{c}89 \\
(26.2 \%) \\
\end{array}$ & $\begin{array}{c}72 \\
(21.2 \%) \\
\end{array}$ & $\begin{array}{c}16 \\
(4.7 \%) \\
\end{array}$ & $\begin{array}{c}14 \\
(4.1 \%) \\
\end{array}$ \\
\hline 6 & I had zeal with online learning. & $\begin{array}{c}126 \\
(37.1 \%)\end{array}$ & $\begin{array}{c}93 \\
(27.4 \%)\end{array}$ & $\begin{array}{c}67 \\
(19.7 \%)\end{array}$ & $\begin{array}{c}38 \\
(11.2 \%)\end{array}$ & $\begin{array}{c}16 \\
(4.7 \%)\end{array}$ \\
\hline 7 & $\begin{array}{l}\text { On online learning, I could } \\
\text { interact with the instructor of } \\
\text { the course through e-mail and } \\
\text { chat. }\end{array}$ & $\begin{array}{c}118 \\
(34.7 \%)\end{array}$ & $\begin{array}{c}94 \\
(27.6 \%)\end{array}$ & $\begin{array}{c}55 \\
(16.2 \%)\end{array}$ & $\begin{array}{c}59 \\
(17.4 \%)\end{array}$ & $\begin{array}{c}14 \\
(4.1 \%)\end{array}$ \\
\hline 8 & The assignments on the online & 115 & 90 & 66 & 58 & 11 \\
\hline
\end{tabular}




\begin{tabular}{|c|l|c|c|c|c|c|}
\hline & $\begin{array}{l}\text { learning course facilitated my } \\
\text { learning. }\end{array}$ & $(33.8 \%)$ & $(26.5 \%)$ & $(19.4 \%)$ & $(17.1 \%)$ & $(3.2 \%)$ \\
\hline 9 & $\begin{array}{l}\text { The instructor was accessible to } \\
\text { answer my questions. }\end{array}$ & $\begin{array}{c}111 \\
(32.6 \%)\end{array}$ & $\begin{array}{c}82 \\
(24.1 \%)\end{array}$ & $\begin{array}{c}80 \\
(23.5 \%)\end{array}$ & $\begin{array}{c}50 \\
(14.7 \%)\end{array}$ & $\begin{array}{c}17 \\
(5.0 \%)\end{array}$ \\
\hline 10 & $\begin{array}{l}\text { The presentation of the internet- } \\
\text { based learning course was clear. }\end{array}$ & $\begin{array}{c}110 \\
(32.4 \%)\end{array}$ & $\begin{array}{c}83 \\
(24.4 \%)\end{array}$ & $\begin{array}{c}87 \\
(25.6 \%)\end{array}$ & $\begin{array}{c}47 \\
(13.8 \%)\end{array}$ & $\begin{array}{c}13 \\
(3.8 \%)\end{array}$ \\
\hline 11 & $\begin{array}{l}\text { The activities were used based } \\
\text { on the objectives of the course. }\end{array}$ & $\begin{array}{c}109 \\
(32.1 \%)\end{array}$ & $\begin{array}{c}92 \\
(27.1 \%)\end{array}$ & $\begin{array}{c}85 \\
(25.0 \%)\end{array}$ & $\begin{array}{c}45 \\
(13.2 \%)\end{array}$ & $9(2.6 \%)$ \\
\hline 12 & $\begin{array}{l}\text { I had access e-learning through } \\
\text { smartphone. }\end{array}$ & $\begin{array}{c}109 \\
(32.1 \%)\end{array}$ & $\begin{array}{c}62 \\
(18.2 \%)\end{array}$ & $\begin{array}{c}55 \\
(16.2 \%)\end{array}$ & $\begin{array}{c}68 \\
(20.0 \%)\end{array}$ & $\begin{array}{c}46 \\
(13.5 \%)\end{array}$ \\
\hline 13 & $\begin{array}{l}\text { The course lessons used on } \\
\text { distance education facilitated } \\
\text { my learning. }\end{array}$ & $\begin{array}{c}107 \\
(31.5 \%)\end{array}$ & $\begin{array}{c}93 \\
(27.4 \%)\end{array}$ & $\begin{array}{c}88 \\
(25.9 \%)\end{array}$ & $\begin{array}{c}41 \\
(12.1 \%)\end{array}$ & $\begin{array}{c}11 \\
(3.2 \%)\end{array}$ \\
\hline 14 & $\begin{array}{l}\text { Online learning abled me to } \\
\text { learn independently. }\end{array}$ & $\begin{array}{c}99 \\
(29.12 \%)\end{array}$ & $\begin{array}{c}80 \\
(23.5 \%)\end{array}$ & $\begin{array}{c}66 \\
(19.4 \%)\end{array}$ & $\begin{array}{c}73 \\
(21.5 \%)\end{array}$ & $\begin{array}{c}22 \\
(6.5 \%)\end{array}$ \\
\hline \multirow{2}{*}{15} & $\begin{array}{l}\text { I was satisfied from the } \\
\text { teaching skills of teachers on } \\
\text { online learning course. }\end{array}$ & $\begin{array}{c}90 \\
(26.5 \%)\end{array}$ & $\begin{array}{c}99 \\
(29.1 \%)\end{array}$ & $\begin{array}{c}81 \\
(23.8 \%)\end{array}$ & $\begin{array}{c}54 \\
(15.9 \%)\end{array}$ & $\begin{array}{c}16 \\
(4.7 \%)\end{array}$ \\
\hline 16 & $\begin{array}{l}\text { On online learning, the teacher } \\
\text { functioned as a facilitator of the } \\
\text { course. }\end{array}$ & $\begin{array}{c}75 \\
(22.1 \%)\end{array}$ & $\begin{array}{c}70 \\
(20.6 \%)\end{array}$ & $\begin{array}{c}93 \\
(27.4 \%)\end{array}$ & $\begin{array}{c}82 \\
(24.1 \%)\end{array}$ & $\begin{array}{l}20 \\
(5.9 \%)\end{array}$ \\
\hline
\end{tabular}

Table 1. the satisfaction of learners from internet-based learning, Kandahar University. The first item asserts that students cannot learn from online learning compare to traditional teaching process $53.5 \%$ because they strongly disagree. In addition, 30.3\% disagree, only $9.1 \%$ were somehow agree, $4.7 \%$ agree and only $2.4 \%$ learners strongly agree since students can learn on the e-learning process. As well as the 2nd item illustrates that $50.9 \%$ students do not have access online learning to follow their lessons through computers. $27.6 \%$ disagree, $10 \%$ learners somehow agree because they have access web-based education. Furthermore, $8.5 \%$ agree and $2.9 \%$ strongly disagree. Likewise, the 3rd statement reveals that $49.7 \%$ students strongly disagree because they do not value to internet-based learning. Therefore, it can be said that students prefer traditional classrooms. Similarly, 27.1\% disagree but $12.1 \%$ somehow agree, 9.4\% agree, and $1.8 \%$ strongly agree. Moreover, the 4th item highlights that $44.4 \%$ students strongly disagree as well $28.8 \%$ learners disagree because they do not get the same descriptions on e-learning as they receive on a traditional classroom. However, $16.5 \%$ students somehow agree, $7.9 \%$ agree, and few learners $2.4 \%$ strongly agree. Additionally, the 5th statement demonstrates that respondents strongly disagree because they do not satisfy from distance education $43.8 \%$ as well as $26.2 \%$ disagree. However, $21.2 \%$ somehow agree, agree $4.7 \%$ and only $4.1 \%$ students strongly disagree.

The 6th item indicates that $37.1 \%$ students strongly disagree because they do not have zeal with online learning and $27.4 \%$ disagree. Whereas, $19.7 \%$ somehow agree, $11.2 \%$ agree and $4.7 \%$ strongly agree. In addition, the 7th line shows that $34.7 \%$ strongly disagree, $27.6 \%$ disagree. However, $16.2 \%$ students can interact with teachers of online learning classroom through chats, $17.4 \%$ agree and less present $4.1 \%$ of learners cannot interact with their teachers. As well, the 8th statement reveals that the assignments do not help students learning 33.8\%, also $26.5 \%$ disagree. Additionally, $19.4 \%$ learners agree. Likewise, $17.1 \%$ agree and $3.2 \%$ strongly 
agree. Furthermore, the 9th item of the table illustrates that $32.6 \%$ students report that teachers do not have access to their questions, and more $24.1 \%$ learners also disagree. Moreover, $23.5 \%$ somehow agree that teachers have access to students' questions, $14.7 \%$ agree and the rest part of the students strongly agree 5\%. Additionally, the 10th item asserts that students strongly disagree $32.4 \%$ because the presentation was not clear on e-learning process and $24.4 \%$ also disagree. Furthermore, $25.6 \%$ of the learners somehow agree, $13.8 \%$ agree and $3.8 \%$ strongly agree.

Similarly, the 11th item indicates that all activities implemented on internet-based learning course were not based on the goals of course $32.1 \%$ and $27.1 \%$ disagreed. Additionally, $25 \%$ somehow agreed, $13.2 \%$ agreed and few percent $2.6 \%$ strongly agreed. Likewise, the 12 th line of the table demonstrates that $32.1 \%$ learners strongly disagree and $18.2 \%$ disagree. Moreover, $16.2 \%$ students somehow agree because they have access web-based learning through smartphones, 20\% agree and 13.5\% strongly agree. Moreover, the 13th item highlights that $31.5 \%$ strongly disagree, and $27.4 \%$ disagree. In addition, $25.9 \%$ somehow agree, $12.1 \%$ agree and $3.2 \%$ students strongly agree that lessons provided on the online learning process helped their learning. Furthermore, shows that $29.1 \%$ students strongly disagree, and $23.5 \%$ disagree that online learning do not able students to learn independently. In addition, $19.4 \%$ somehow agree, $21.5 \%$ agree and $6.5 \%$ students strongly agree. Also, the 15 th item asserts that $26.7 \%$ learners were not satisfy from teaching skills of their teachers as well $29.1 \%$ disagree. Moreover, $23.8 \%$ somehow agree, $15.9 \%$ agree and $4.7 \%$ strongly agree. The last item indicates that $22.1 \%$ leaners strongly disagree and $20.6 \%$ disagree. As well, $27.4 \%$ students somehow agree that teachers only instruct them during online learning. Likewise, $24.1 \%$ agree, and $5.9 \%$ strongly agree.

\section{DISCUSSION}

The findings of this study showed that majority students of Education Faculty at Kandahar University cannot learn from online learning compare to traditional classroom environment. Through this it can be said that students can learn better on a traditional way because they were not satisfied from online learning. The finding of this study is not line with a study conducted by Zaheer et al., (2015) in Pakistan that majority students were highly satisfied from distance learning provided by the University. In addition, whereas the finding of this study is supported more that this finding is not in line with a comparative study conducted in Pakistan to compare the level of students' satisfaction at (AIOU) distance learning and International Islamic University's traditional classroom programs of educational psychology course taught by the same instructor. The findings asserted that distance learning and traditional classroom students experienced a high level of satisfaction. Moreover, it was determined that there was very slightly variance in the levels of learners' satisfaction in the e-learning and traditional classroom students (Mahmood, et al., 2012).

The finding of this study asserted that students do not have access to internet-based learning through computer (desktops or laptops). It can be inferred that students do not have electronic devices in order to access e-learning teaching process because they were not satisfied. As well as, it can be imagined that students do not have access to technology. Therefore, it can be said that learners cannot learn through e-learning process because they do not have access to online learning. This finding can be somehow supported by Sunkara et al., (2017) because the findings of their study disclosed that students are not fully satisfied from distance learning 
whereas $77.49 \%$ of them were comfortable in using internet and web services for learning while $51.93 \%$ always able to use technology and internet for learning process. The finding of this study is also not in accordance with a study conducted by Himat, (2020) at Mirwais Khan Nika Zabul Institute of Higher Education, Education Faculty, Zabul, Afghanistan. He stated in his research that the citizens of Afghanistan, especially students who are studying at institutions and universities have access to technology.

Likewise, the next finding indicated that students do not prefer web-based learning. It means that they value traditional environment of learning. This finding is against with Irungu (2016) because the results asserted that large extent of students were satisfied from online learning which offered through the School of Continuing and Distance Studies at University of Nairobi, Kenya. As well, majority respondents showed their satisfaction by stating that they would still enroll through distance education. Similarly, the research indicated more that students' preferred distance learning as opposed to regular classroom-based learning. Similarly, many learners asserted that their expectations were met through the programme and respondents stated more that they will encourage their friends and relatives to enroll distance learning. Additionally, the finding of this study asserted more that students do not seek the same descriptions of lessons on online learning compare to traditional method of classroom. It can be inferred that learners did not receive the explanations of teaching materials through web-based learning as they received in the face to face classrooms. The finding of this study is not in match with Simpson (2012) who carried out a study to examine students' perceptions of quality and satisfaction in regionally accredited online courses on ten different institutions. The findings revealed that students are highly satisfied because the students were comfortable when they received lessons through online mode.

Furthermore, the findings revealed that online learning did not able majority students to learn independently. It can be said that students were belonged on teachers, and they were not left alone to work and learn from their own selves This finding of this research is not in line with Sahin (2007) that distance education is student-centered method because lecturer only support such as, timely assist, useful feedback, and easy communication is still a key factor for students' satisfaction on distance education. Similarly, the finding indicated that students of Education Faculty at Kandahar University were not satisfied from teaching skills of teachers in web-based learning courses. Through this it can said that teachers may not have good plan in order to teach students as well they may not work based on the stated objectives in the course syllabus. The finding of Roach et al., (2006) is not in accordance with this current study finding because their findings indicated that students on online program were satisfied with the courses.

Besides, the findings of this study showed more that students were somehow satisfied because teachers played their role on the internet based learning courses as a facilitator. Through this it can be said that teachers were only instruct students in order to learn teaching materials. This finding can be supported by a research conducted at Anatolian University on 917 learners in Turkey by Sahin (2007) that distance education is student-centered method because teachers only assist students and show ways what to do. In all, the findings showed that more than half 
$(50+\%)$ of the respondents were not satisfied from online learning. This finding is somehow in line with Arif et al., (2017) carried out a research on students' satisfaction with the use of webbased services at (AIOU), Pakistan. The findings of this study revealed that majority of the students $(82 \%)$ were satisfied from the use of web-based services.

\section{CONCLUSION}

This research used a quantitative method in order to find the satisfaction of Education Faculty's learners from online learning during coronavirus at Kandahar University. The participants were 340, and they were elected by applying random sampling method. Also, many participants of the study were male than female learners. In addition, the findings of this study revealed that majority leaners were dissatisfied from internet-based learning for several causes because they could not learn from online learning compare to traditional classroom setting, learners did not have access to internet-based learning through computer, students did not favor web-based learning, students did not seek the same descriptions of lessons on online learning than traditional method of classroom, online learning did not able students to learn independently, but approximately $27.4 \%$ students were somehow satisfied from the role of lecturers who played their role as a facilitator on the distributed learning courses.

\section{SUGGESTIONS}

This current study investigated the satisfaction of students from internet-based learning of Education Faculty at Kandahar University during COVID-19 pandemic. Therefore, the following suggestions are important based on the findings of this research to be noted in future. First, as students did not have access to online learning; consequently, if the Ministry of Higher Education (MoHE) of Afghanistan attract the attention of the Ministry of Information and Communications Technology (MICT) to develop a policy in order to make the price of internet cheap for the students, it will help with students to get higher education through online learning without lots of barriers. As well, as it is clear that Afghanistan is one of those countries which have many poor people and have low income because this issue is essential to be cleared. Secondly, if the (MICT) work for the quality of internet, it will assist not only with learners, it will also help with the rest residents of country because the quality of internet has relation with students' satisfaction from online learning. Third, if the (MoHE) of Afghanistan extend the access of internet from cities to districts or far away villages of cities, students will be able to access online learning from their homes. Moreover, the following suggestions are given for further studies to investigate the advantages and disadvantages of online learning, perceptions of teachers and students about online learning, impacts of e-learning on learners' academic performance and the challenges of internet-based learning from the perspective of lecturers and students.

\section{REFERENCES}

Agbanu, P. G., Sonyo, E., Region, V., \& Ahiase, G. G. (2018). Examining Factors Influencing Student Satisfaction in Distance Education in Ghana: A Study of the Institute for Educational Development and Extension, University of Education, Winneba. The Online Journal of Distance Education and e-Learning, 6(1), 32. 
Ajadi, T. O., Salawu, I. O., \& Adeoye, F. A. (2008). E-learning and distance education in Nigeria. Online Submission, 7(4).

Ala-Mutka, K., Punie, Y., \& Redecker, C. (2008). Digital competence for lifelong learning. Institute for Prospective Technological Studies (IPTS), European Commission, Joint Research Centre. Technical Note: JRC, 48708, 271-282.

Al-Asfour, A. (2012). Examining student satisfaction of online statistics courses. Journal of College Teaching \& Learning (TLC), 9(1), 33-38. https://doi.org/10.19030/tlc.v9i1.6764

Ali, A., Ramay, M. I., \& Shahzad, M. (2011). Key factors for determining student satisfaction in distance learning courses: A study of Allama Iqbal Open University (AIOU) Islamabad, Pakistan. Turkish Online Journal of Distance Education, 12(2), 114-127.

Allen, I. E., \& Seaman, J. (2015). Grade Level: Tracking Online Education in the United States. Babson Survey Research Group. Babson College, 231 Forest Street, Babson Park, MA 02457.

Anagnostopoulou, E., Mavroidis, I., Giossos, Y., \& Koutsouba, M. (2015). Student Satisfaction in the Context of a Postgraduate Programme of the Hellenic Open University. Turkish Online Journal of Distance Education, 16(2), 40-55.

Apena, T. T. (2012). Information and Communication Technology and Open Distance Learning, Impact and Challenges. International Journal of Social Sciences \& Education, 2(1).

Arif, M., Ameen, K., \& Rafiq, M. (2017). Assessing distance education students' satisfaction with web-based services: A Pakistani's perspective. Online Information Review, Vol. 41 No. 2, pp. 202-218. https://doi.org/10.1108/OIR-07-2016-0172

Arif, R. M., \& Khalifa, O. O. (2012). Online tutoring system in college: Case study in private education. In 2012 International Conference on Computer and Communication Engineering (ICCCE) (pp. 608-611). IEEE. https://doi.org/10.1109/ICCCE.2012.6271259

Askar, P., \& Halici, U. (2004). E-learning as a catalyst for educational innovation. In EEducation Applications: Human Factors and Innovative Approaches (pp. 196-207). IGI Global.

Bray, E., Aoki, K., \& Dlugosh, L. (2008). Predictors of learning satisfaction in Japanese online distance learners. The International Review of Research in Open and Distributed Learning, 9(3). https://doi.org/10.19173/irrodl.v9i3.525

Caliskan, S., Suzek, S., \& Ozcan, D. (2017). Determining student satisfaction in distance education courses. Procedia computer science, 120, 529-538. https://doi.org/10.1016/j.procs.2017.11.275 
Franklin, U. E., \& Nahari, A. A. (2018). The Impact of e-learning on academic performance: preliminary examination of King Khalid University. DEVELOPMENT, 7(1). http://dx.doi.org/10.6007/IJARPED/v7-i1/3903

Harsasi, M., \& Sutawijaya, A. (2018). Determinants of Student Satisfaction in Online Tutorial: A Study of a Distance Education Institution. Turkish Online Journal of Distance Education, 19(1), 89-99.

Himat, A. (2020). The Effects of Facebook on Students' Social Life: A Case Study at Mirwais Khan Nika Zabul Institute of Higher Education, Zabul. American International Journal of Social Science Research, 5(3); 7-16. https://doi.org/10.46281/aijssr.v5i3.593

Irungu, M. B. (2016). Factors influencing learners' satisfaction with distance learning: a case of bachelor of arts University of Nairobi, Kenya (Doctoral dissertation, University of Nairobi).

Jama, M. P., Mapesela, M. L., \& Beylefeld, A. A. (2008). Theoretical perspectives on factors affecting the academic performance of students. South African Journal of Higher Education, 22(5), 992-1005.

Koustourakis, G., Panagiotakopoulos, C., \& Vergidis, D. (2008). A Contribution to the Hellenic Open University: Evaluation of the pedagogical practices and the use of ICT on distance education. The International Review of Research in Open and Distributed Learning, 9(2). https://doi.org/10.1016/j.sbspro.2012.05.556

Kuo, Y. C., Walker, A. E., Belland, B. R., \& Schroder, K. E. (2013). A predictive study of student satisfaction in online education programs. International Review of Research in Open and Distributed Learning, 14(1), 16-39.https://doi.org/10.19173/irrodl.v14i1.1338

Kutluk, F. A., \& Gulmez, M. (2012). A research about distance education students' satisfaction with education quality at an accounting program. Procedia-Social and Behavioral Sciences, 46, 2733-2737. https://doi.org/10.1016/j.sbspro.2012.05.556

Lao, T., \& Gonzales, C. (2005). Understanding online learning through a qualitative description of professors and students' experiences. Journal of Technology and Teacher Education, 13(3), 459-474.

Mahmood, A., Mahmood, S. T., \& Malik, A. B. (2012). A Comparative Study of Student Satisfaction Level in Distance Learning and Live Classroom at Higher Education Level. Turkish Online Journal of Distance Education, 13(1), 128-136.

Michailidou, A., \& Economides, A. A. (2003). Elearn: Towards a collaborative educational virtual environment. Journal of Information Technology Education: Research, 2(1), 131152.

Moore, M. G., \& Kearsley, G. (1996). Distance learning: A systems view. New York: Wadsworth. 
Nadia, A. Y. U. B., \& Iqbal, S. (2011). Student Satisfaction with e-Learning achieved in Pakistan. Asian Journal of Distance Education, 9(2), 26-31.

Northrup, P. T. (2009). Online learners' preferences for interaction. The perfect online course: Best practices for designing and teaching, 463-473.

Olusola, A. J., \& Alaba, S. O. (2011). Globalization, Information and Communication Technologies (ICTs) and Open/Distance Learning in Nigeria: Trends, Issues and Solution. Turkish Online Journal of Distance Education, 12(3), 66-77.

Roach, V., \& Lemasters, L. (2006). Satisfaction with online learning: A comparative descriptive study. Journal of Interactive Online Learning, 5(3), 317-332.

Sahin, L. (2007). Predicting Student Satisfaction and Distance Education and Learning Environments. Online Submission.

Salamat, L., Ahmad, G., Bakht, I., \& Saifi, I. L. (2018). Effects of E-Learning on Students' Academic learning at University Level. Asian Innovative Journal of Social Sciences and Humanities, 2(2), 1-12.

Simpson, J. M. (2012). Student perceptions of quality and satisfaction in online education (Doctoral dissertation, University of Alabama Libraries).

Sokout, H., \& Usagawa, T. (2018). Analyzing the Current Situation of E-learning at Kabul Polytechnic University. In Proceedings of the 2nd International Conference on Education and Multimedia Technology (pp. 49-53). https://doi.org/10.1145/3206129.3239428

Sunkara, V. M., \& Kurra, R. R. (2017). An analysis of learner satisfaction and needs on elearning systems. International Journal of Computational Intelligence Research, 13(3), 433444.

Swan, K. (2001). Virtual interaction: Design factors affecting student satisfaction and perceived learning in asynchronous online courses. Distance education, 22(2), 306-331. https://doi.org/10.1080/0158791010220208

Swan, K., Shea, P., Fredericksen, E., Pickett, A., Pelz, W., \& Maher, G. (2000). Building knowledge building communities: Consistency, contact and communication in the virtual classroom.Journal of Educational Computing Research,23(4), 359-383. https://doi.org/10.2190\%2FW4G6-HY52-57P1-PPNE

Wang, Q., \& Woo, H. L. (2007). Systematic planning for ICT integration in topic learning. Journal of Educational Technology \& Society, 10(1), 148-156. 
Wantling, T. L., Weight, C., Gallaher, J. L. A., Fleur, J., Wang, C., \& Confer, A. (2000). ELearning: A Review of Literature' Knowledge and Learning Systems Group, University of Illinois: Urbana.

Yukselturk, E., \& Yildirim, Z. (2008). Investigation of interaction, online support, course structure and flexibility as the contributing factors to students' satisfaction in an online certificate program. Journal of Educational Technology \& Society, 11(4), 51-65.

Zaheer, M., Babar, M. E., Gondal, U. H., \& Qadri, M. M. (2015). E-learning and student satisfaction. In Proceedings of the 29th Annual Conference of the Asian Association of Open Universities: New frontiers in ODL (pp. 275-285).

\section{Copyrights}

Copyright for this article is retained by the author(s), with first publication rights granted to the journal. This is an open-access article distributed under the terms and conditions of the Creative Commons Attribution license (http://creativecommons.org/licenses/by/4.0/) 